\author{
ŻANETA TEMPCZYK-NAGÓRKA* \\ Warszawa, Polska \\ ORCID ID: http://orcid.org/oooo-00o2-0440-0218
}

\title{
OD DZIECI ULICY DO DZIECI CYBERULICY
}

Streszczenie: Zjawisko dzieci ulicy, coraz lepiej poznawane, poddawane analizom teoretycznym i empirycznym oraz przyjmujące różne oblicza w zależności od środowiska gospodarczo-kulturowego, w którym funkcjonuje, w zderzeniu z rozwojem technologicznym społeczeństw informacyjnych, zaczyna ulegać w swych pewnych obszarach przekształceniom. W wyniku tego procesu z części grupy dzieci ulicy, wywodzących się z domów o dobrym statusie materialnym, lecz zaniedbanych emocjonalnie, pozostawionych samym sobie i wędrujących bez rodzicielskiej kontroli po świecie wirtualnym, wyłania się grupa, którą można określić jako „dzieci cyberulicy”. Celem artykułu jest ukazanie powiązań między tymi zjawiskami zarówno w obszarze części uwarunkowań, form aktywności podejmowanych przez dzieci, zagrożeń, jak i założeń profilaktyczno-pomocowych.

Słowa kluczowe: dzieci ulicy; zagrożenia cyberprzestrzeni; streetworking; networking; niewydolność rodziny.

\section{Wstęp}

Rozwój cywilizacyjny, gospodarczy oraz technologiczny, przyczyniający się do zmian demograficznych i warunków życia ludzi, pociąga za sobą przekształcenia w obrębie dotychczasowych zjawisk i problemów społecznych. Szczególnie jest to znamienne w krajach o wysokim rozwoju cywilizacyjnym i technologicznym, zdominowanych przez media elektroniczne i internet, będący coraz częściej nieodłącznym elementem życia. W obliczu wspominanych zmian wyłania się nowa

* Dr Żaneta Tempczyk-Nagórka, Uniwersytet Kardynała Stefana Wyszyńskiego w Warszawie, Wydział Nauk Pedagogicznych; e-mail: z.tempczyk@uksw.edu.pl. 
forma zjawiska dzieci ulicy. Dzieci, które są pozbawione uwagi i należytej troski ze strony opiekunów, kiedyś zasilały ulice i podwórka, coraz częściej zaczynają spędzać czas przed komputerem czy z telefonem w ręku, w przestrzeni wirtualnej, która wcale nie musi być bezpieczniejsza od ulicy. Cyberprzestrzeń zaspokaja ich potrzeby, tak jak wcześniej robiła to ulica i podwórka, roztaczające wiele możliwości po zamknięciu drzwi domu lub placówki. Na wirtualnej ulicy jest bardzo podobnie: „Mechanizm jest prosty: «Wchodzę do sieci», przenoszę się w inny świat, zaczynam należeć do elitarnego kręgu. Tu liczę się ja. Nie ważne, jak wyglądam. Jeśli mi ktoś nie odpowiada, zmieniam go" (Kozak 2011, s. 11).

Celem artykułu jest ukazanie powiązań między zjawiskami dzieci ulicy realnej i wirtualnej. Zaprezentowane w artykule rozważania mają prowadzić do konkluzji, że żadna ulica, ani ta realna, ani ta wirtualna, nie jest właściwym miejscem dla życia i rozwoju dzieci.

\section{Wokół pojęcia i kategorii „dzieci ulicy”}

Pojęcie „dzieci ulicy” jest trudne do zdefiniowania ze względu na wielkość zjawiska, do którego się odnosi, mnogość kultur, w których występuje, zróżnicowaną etiologię i odmienne oblicza, jakie przyjmuje. Przeglądu definicji analizowanego pojęcia dokonała m.in. Barbara Adamczyk (2015), wskazując, że proponowane są definicje zarówno teoretyczne, jak i utylitarne, ukazujące różne elementy tego fenomenu: patologizację życia, formy ulicznej aktywności, ilość czasu spędzanego na ulicy, poziom więzi z domem rodzinnym, dysfunkcyjność środowisk wychowawczych itp. Rada Europy po realizacji projektu badawczego w 24 krajach europejskich zaproponowała następującą ogólną definicję: „Dzieci ulicy to dzieci poniżej 18 roku życia, które przez krótszy lub dłuższy czas żyją w środowisku ulicznym. Dzieci te żyją, przenoszą się z miejsca na miejsce i nawiązują kontakty z grupą rówieśniczą lub innymi grupami na ulicy. Oficjalnym adresem tych dzieci jest adres rodziców lub jakiejś instytucji socjalnej (pomocy wychowawczej, poradni psychiatrycznej dla młodzieży i in.). Wysoce znamiennym jest przy tym to, że z dorosłymi, rodzicami oraz przedstawicielami szkół i instytucji pomocowych dzieci te mają jedynie słaby lub żaden kontakt" (Counsil of Europe, 1994, cyt. za: Brades, Specht 2000, s. 29-30).

Jednak poza Europą omawiane zjawisko jest również bardzo żywe i przybiera jeszcze drastyczniejsze formy. W krajach Ameryki Południowej i Afryki dzieci przebywają w warunkach skrajnego ubóstwa. Żyjąc na ulicach czy dworcach, są pozbawione rodzin, ścigane za kradzież kromki chleba lub żebranie pod sklepem, a nawet zabijane przez specjalnie wynajętych snajperów (Kurzeja 2008). W regionach dotkniętych wojnami, w tym wojnami domowymi, dzieci wielokrotnie zostają rozdzielone z rodzinami albo tracą rodziców w wyniku walk. Zostają pozbawione nie tylko najbliższych, lecz także dachu nad głową. Są zdane na samych siebie, łączą się w grupy, aby łatwiej było im przetrwać, cierpią głód i prostytuują się, aby zarobić na jedzenie (Babicki 2017). Tadeusz Pilch (2010), powołując się na raport wydany 
przez UNICEF, przytacza dramatyczne dane statystyczne, w świetle których aż $640 \mathrm{mln}$ dzieci na świecie nie ma dachu nad głową, $500 \mathrm{mln}$ jest pozbawionych podstawowych warunków higieny, $400 \mathrm{mln}$ nie ma dostępu do czystej wody, $250 \mathrm{mln}$ dzieci podejmuje pracę, w tym ok. $10 \mathrm{mln}$ pracuje niewolniczo. Można domniemać, że większość tych dzieci to właśnie dzieci ulicy.

W przestrzeni globalnej rozróżnia się jeszcze pojęcia „dzieci ulicy” i „dzieci na ulicy”. Pierwsze odnosi się do dzieci, które żyją i mieszkają na ulicy, nie mają swojego domu lub nie chcą w nim przebywać. Drugie określenie dotyczy dzieci przebywających na ulicy w ciągu dnia, w tym w godzinach szkolnych, ale wracających do domu na noc (Adamczyk 2015; Kołodzieczyk 200o).

Dzieci ulicy żyją na wszystkich zurbanizowanych kontynentach, zarówno w dużych miastach, jak i na ich peryferiach. Trudno zatem przyjąć jednoznaczną definicję dzieci ulicy, gdyż analizowane pojęcie może być rozumiane różnorodnie, w zależności od struktury społeczno-kulturalnej danego państwa (Fidelus 2005a). Dlatego zasadne wydaje się spojrzenie, jak określany jest ten fenomen na gruncie polskim. W polskiej rzeczywistości zakres semantyczny pojęcia „dzieci ulicy” wykracza poza klasyczną definicję stworzoną przez Radę Europy, uwzględniając również te dzieci, które, choć mieszkają w domu swoich rodziców i w mniejszym lub większym stopniu uczestniczą w systemie edukacyjnym, to większość swojego czasu spędzają na ulicy, poza domem i poza wszelką kontrolą osób dorosłych, wśród swoich rówieśników znajdujących się w podobnej sytuacji. Przykładem może być utylitarna definicja wypracowana przez Krajowy Komitet Wychowania Resocjalizującego KKWR, a przytoczona przez Wiesława Kołaka: „dzieci ulicy to te, które na skutek niespełnienia przez ich rodziców podstawowych funkcji opiekuńczych i wychowawczych dużo czasu spędzają poza domem - na ulicy, na podwórku i innych miejscach niekontrolowanej aktywności. Ulica stała się dla nich źródłem wiedzy o życiu. Tu realizują swoją naturalną aktywność poznawczą i społeczną. [...] dzieckiem ulicy jest się tym bardziej, im więcej funkcji przypisanych rodzinie przejmuje ulica" (2002, s. 5). Do cech charakteryzujących dziecko ulicy Grażyna Olszewska-Baka i Lesław Pytka (2000) zaliczają:

- $\quad$ odrzucenie lub opuszczenie emocjonalne, psychiczne i społeczne przez rodziców;

- pozbawianie opieki i możliwości zaspokojenia potrzeb rozwojowych w środowisku rodzinnym;

- zaniedbanie wychowawcze i socjalizacyjne;

- pochodzenie z rodziny dysfunkcjonalnej, bez prawidłowych wzorów zachowań;

- identyfikację z podkulturą przestępczą, z którą jest związane;

- manifestację zachowań antyspołecznych, niezgodnych z normami ról społecznych;

- doświadczanie przemocy lub wykorzystania; 
- $\quad$ brak realizacji obowiązku szkolnego lub pozbawienie stałej opieki instytucjonalnej placówki edukacyjno-opiekuńczej;

- $\quad$ życie i samorealizacja w miejscach poza kontrolą i wpływem dorosłych oraz destruktywny sposób funkcjonowania (żebractwo, kradzieże, włóczęgostwo, uzależnienia, zachowania agresywne).

Powyższe rozważania rysują obraz polskiego dziecka ulicy, jednak jest on wciąż niejednolity i wieloznaczny. Jego uzupełnienie stanowią różnorodne i obszernie prezentowane kategorie i typologie dzieci ulicy, dokonywane w oparciu o rozmaite kryteria, np. wieku, przyczyn pojawienia się na ulicy, podejmowanej aktywności na ulicy czy ilości spędzanego tam czasu (Kurzeja 2008; Adamczyk 2015). Irena Pospiszyl (2014) wymienia następujące kategorie dzieci ulicy: uciekinierzy (dzieci pochodzące najczęściej z rodzin z deficytem relacji emocjonalnych i rodzin biednych oraz dzieci niezintegrowane ze środowiskiem szkolnym); poszukiwacze przygód (nie mogą liczyć na uwagę rodziców, wyizolowane w domu i szkole, marzą o przeżyciu przygody, często uciekają z domu na parę dni, są mało zaradne w porównaniu z innymi dziećmi ulicy); włóczędzy, ulicznicy, „uliczni królewicze”, gawrosze (świetnie się odnajdują na ulicy: potrafią znaleźć nocleg, posiłek, ukraść lub zarobić pieniądze, np. żebrząc, zbierając złom, prostytuując się, często tworzą bandy); galerianki (nastolatki zarabiające przez prostytuowanie się); blokersi, dzieci podwórkowe (najczęściej spotykają się w okolicach miejsca zamieszkania, kończą edukację na dość wczesnym etapie, niszczą otoczenie, np. malują graffiti, śmiecą); buntownicy bez powodu (zbuntowani wobec rodziców i dorosłych, nieodporni na uzależnienia i radykalne ideologie, pasywni - bez skonkretyzowanych celów życiowych, zaniedbani emocjonalnie).

Tadeusz Kołodziejczyk (200o) przedstawił swoją propozycję typologii dzieci ulicy, koncentrując się na ukazaniu różnych rodzajów problemów, z jakimi się borykają: (1) dzieci Cyganów rumuńskich; (2) chłopcy i dziewczęta prostytuujące się; (3) dzieci uciekające z domów rodzinnych; (4) dzieci, które nie spełniają obowiązku szkolnego, pochodzące najczęściej z rodzin patologicznych, nocujące w domu, ale spędzające całe dnie na ulicy; (5) uciekający z placówek opiekuńczych lub oczekujący na miejsce w tych placówkach; (6) dzieci pracujące na ulicy (wybierane przez nich prace to: żebractwo, włamania, kradzieże, mycie szyb samochodowych itp.); (7) dzieci spędzające większość swojego czasu na ulicy, ich domy bowiem nie są dla nich bezpiecznymi miejscami, pozbawionymi wsparcia. Dla tych dzieci ulica jest koniecznością, a nie wyborem, jest szansą na zaspokojenie podstawowych potrzeb. Do tych kategorii Anna Kurzeja (2008) dodaje jeszcze „dzieci z kluczem u szyi”, czyli takie, które same sprawują nad sobą opiekę po szkole, do czasu powrotu rodziców z pracy. Dzieci z tej kategorii, mimo posiadania domu rodzinnego, przez znaczną część dnia pozbawione są kontroli ze strony opiekunów.

Warto jeszcze przytoczyć typologię zaproponowaną przez G. Olszewską-Bakę i L. Pytkę (1999), którzy obok dzieci pochodzących z rodzin dysfunkcyjnych, dzieci wychowujących się w niebezpiecznych domach (w których panują uzależnienia, 
przemoc, wykorzystanie seksualne itp.), dzieci o szczególnym temperamencie i cechach osobowości, pragnące niezależności, braku kontroli i przygód, którym ulica zapewnia odpowiednią ilość stymulacji, wymienia dzieci z rodzin tzw. normy. Ta ostatnia grupa jest szczególna, rodziny tych dzieci mają bowiem dobry lub wysoki status materialny, jednak rodzice, ambitni i skoncentrowani na zyskach materialnych, zajęci są pracą zawodową lub karierą i nie tworzą z dziećmi więzi emocjonalnych oraz nie radzą sobie z problemami wychowawczymi. Podobnie o dzieciach ulicy wypowiada się Beata Bednarczyk w rozmowie z Marzeną Kostką (1998), wskazując, że przypisywana tym dzieciom bieda nie musi odnosić się do dóbr materialnych, lecz do ubóstwa emocjonalnego w domu rodzinnym.

Uwarunkowania zjawiska, jakim są dzieci ulicy, wynikają w pewnym stopniu z przytoczonych kategorii i są bardzo różnorodne, w zależności od grupy, jakiej dotyczą. Dodatkowo Anna Fidelus (2005b) wskazuje na to, że fenomen dzieci ulicy jest w Polsce konsekwencją przemian społecznych, ekonomicznych i prawnych, bezrobocia, migracji zarobkowej, dezintegracji ogniska domowego, braku właściwych dla rozwoju dzieci warunków bytowych, ubóstwa i rozwijających się na tym gruncie patologii.

Z powyższych ustaleń wynika, że dla uchwycenia istoty omawianego zjawiska w Polsce należałoby uznać pojęcie „dzieci ulicy” jako określenie dla dzieci ulicy i dzieci na ulicy, czyli zarówno dla młodych osób, które są całkowicie pozbawione domu i opieki instytucjonalnej ze strony osób dorosłych, jak również te, które ten dom mają, ale wybierają ulice i podwórka $\mathrm{z}$ powodu braku emocjonalnej więzi $\mathrm{z}$ rodzicami, braku wsparcia i zrozumienia w domu, niespełniania przez rodziny w należyty sposób przypisanych im funkcji, ale także ze względu na brak lepszego pomysłu i alternatyw na spędzanie swojego czasu. Na ulicę trafiają zatem nie tylko dzieci pozbawione rodzin lub wywodzące się z rodzin zaniedbanych, ubogich, patologicznych, lecz także te, które pochodzą z dobrych lecz chłodnych domów, w których rodzice nie mają chęci lub czasu na budowanie więzi z dziećmi oraz bagatelizują ich problemy. Dopiero więc na ulicy, wśród podobnych sobie rówieśników, dzieci te znajdują zrozumienie i akceptację (Fidelus 2005a).

\section{Ewolucja fenomenu dzieci ulicy do dzieci cyberulicy}

W ujęciu biologicznym ewolucja jest procesem polegającym na zmianie sposobu funkcjonowania określonego gatunku lub jego części w wyniku dostosowywania się do zmieniających się warunków środowiska. Na gruncie społecznym częściej wzmiankuje się o rozwoju czy transformacji niż o ewolucji określonych grup czy zjawisk. Jednak w przypadku fenomenu dzieci ulicy te określenia wydają się mało trafne. Rozwój zawiera w sobie konotację pozytywną i sugerowałby polepszenie się sytuacji dzieci, co niestety mija się z prawdą. Natomiast transformacja zakładałaby całkowite przekształcenie się tego zjawiska w nową formę, gdy tymczasem omawiany proces dotyczy tylko części dzieci ulicy. Postęp cywilizacyjny, a zwłaszcza 
technologiczny, zauważalny w ostatnich dekadach w krajach rozwiniętych, spowodował znaczne zmiany w warunkach życia ludzi: rozwój technologii komunikacyjnych i informacyjnych przyczynił się z jednej strony do „zmniejszenia się” świata, a z drugiej do powstawania niezliczonych światów wirtualnych (Tempczyk-Nagórka 2016), przyspieszyło tempo życia, zmieniły się ludzkie aktywności, a także formy spędzania czasu wolnego przez dorosłych, młodzież i dzieci. Informatyzacja i cyfryzacja przyczyniły się do powstania i rozwoju społeczeństwa informacyjnego, w którym właściwie każdy obywatel posiada dostęp do technologii informacyjnych i komunikacyjnych (Żelazny 2014). W obliczu tych wszystkich przemian niektóre zjawiska społeczne, ściśle osadzone w warunkach gospodarczo-kulturowych danych państw, w tym również zjawisko dzieci ulicy, musiały też poddać się częściowej ewolucji, która w tej sytuacji była normalnym procesem przystosowawczym do nowych warunków życia w tych krajach. Powstało zatem nowe zjawisko społeczno-kulturowe, które można nazwać, analogicznie do jego „przodka” (dzieci ulicy) dziećmi cyberulicy. Elementy, które przyczyniły się do powstania tego nowego zjawiska, to przede wszystkim:

- $\quad$ rozwój technologii komunikacyjnej i cyfrowej;

- $\quad$ łatwy dostęp do urządzeń umożliwiających uczestnictwo w sieci informatycznej i/lub komunikacyjnej (komputer, laptop, tablet, iPad, smartfon, iPhone itp.);

- $\quad$ szeroki wpływ mediów na życie społeczne, rodzinne i rozwój tożsamości młodego człowieka;

- $\quad$ powszechne przekonanie, że lepiej jest, aby dziecko było w domu niż poza nim, ponieważ wtedy dorośli mają kontrolę nad tym, co ono robi (kontrola ta jest jednak jedynie pozorna);

- naturalnie odroczona reakcja instytucji społecznych, praktyków i teoretyków zajmujących się wsparciem rozwoju dzieci i młodzieży na gwałtownie postępujące po sobie zmiany społeczne (najpierw pojawiają się nowe zjawiska, problemy i zagrożenia, potem są one identyfikowane dzięki projektom badawczym, poznajemy ich uwarunkowania, przejawy i skutki, następnie wypracowywane są teoretyczne programy profilaktyczno-naprawcze, które najczęściej przed wprowadzeniem w życie wymagają jeszcze odpowiedniego przygotowania realizatorów - całość jest procesem długotrwałym, zazwyczaj wieloletnim).

Nie można mówić o całkowitej transformacji klasycznych dzieci ulicy do nowego zjawiska, jakim jest życie na ulicy cybernetycznej. Jest to proces ewolucyjny obejmujący tylko część dotychczasowych dzieci ulicy, jednak tę część, która w krajach społeczeństwa informacyjnego jest bardzo liczna. Chodzi o dzieci, które chociaż mają dom rodzinny, to nie mają wystarczającej uwagi i wsparcia ze strony rodziców. To właśnie z opisanej wcześniej kategorii dzieci pochodzących z rodzin tzw. normy społecznej rekrutuje się najwięcej dzieci cyberulicy. Dzieci ulicy nie zniknęły całkowicie $\mathrm{z}$ naszych miast, jednak niektóre $\mathrm{z}$ nich, które jeszcze 20 lat 
temu trafilyby na podwórka i pod bramy osiedlowe, teraz zostają w domu, przed komputerem czy $\mathrm{z}$ telefonem komórkowym w ręku, wchodząc w różne, nieraz ciemne zaułki świata wirtualnego.

\section{Uwarunkowania zjawiska dzieci cyberulicy}

Jedną z najbardziej podstawowych przyczyn spędzania przez młodzież czasu na cyberulicy jest postępujący rozpad więzi rodzinnych spowodowany brakiem wspólnie spędzanego czasu, brakiem komunikacji pomiędzy członkami rodziny, zapracowaniem, doświadczaniem kryzysów i trudności, w których pokonywaniu często brakuje cierpliwości i wytrwałości, zwłaszcza w dobie szybkich działań, natychmiastowości i automatycznej gratyfikacji, charakterystycznych dla „kultury szybkostrzelnej" (Drapała-Petryka 2014; Tempczyk-Nagórka 2016). Z tego powodu konflikty w rodzinach się nawarstwiają, a to powoduje silny dystres u dzieci, zwłaszcza wtedy, gdy sposób rozwiązywania konfliktu jest destruktywny (Lachowska 2010). Członkowie rodzin żyją obok siebie, ale nie żyją razem, ich relacje są spłycone lub żadne, często ograniczone do wykonywania zadań domowych. To właśnie nieprawidłowe działanie rodziny, zdaniem różnych autorów (Pilch 2000; Brzeziński 2013; Olszewska-Baka, Pytka 200o), stoi u podstaw zjawiska, jakim jest istnienie dzieci ulicy oraz dzieci cyberulicy. W przestrzeni wirtualnej zawsze jest ktoś on-line, zawsze ktoś czeka, a nawet jeśli nie on sam, to istnieją komputer, telefon, internet, które oferują wiele możliwości.

Na cyberulicę wchodzą również dzieci i młodzież doświadczający nudy, braku perspektyw i pomysłów na spędzenie (lub zabicie) czasu. Potrzebują stymulacji, aktywności, doznań oraz kontaktu z innymi, interakcji międzyludzkich. Te ostatnie są często powierzchowne i ograniczają się do wymiany komentarzy na forum lub na portalach społecznościowych. Dodatkowo świat wirtualny, a zwłaszcza gry komputerowe i sieciowe stwarzają przestrzeń do tworzenia wielu tożsamości, wcielania się w role, dzięki którym można uciec od szarej, smutnej rzeczywistości i problemów z nią związanych; mogą być rozrywką tylko dla jednej osoby, nie wymagają obecności innych osób, choć ją dopuszczają; zapewniają pewne poczucie bezpieczeństwa, komputer bowiem nie zakpi z porażki, lecz stworzy możliwość powtórnej rozgrywki (Krzystanek 2004).

Dzieci doświadczające braku wsparcia, bez więzi i kontaktów z rodzicami, posiadające krzywdzące doświadczenia z domu rodzinnego, są bardziej narażone na niskie poczucie własnej wartości (Bardziejewska 2004; Ryś 2011). Zależy ono również od doświadczanych przez dziecko sukcesów w subiektywnie ważnych dla niego obszarach życia (Trzebińska 2008). Jeśli dziecko doświadcza częstych porażek i krytyki, zaczyna szukać nowych płaszczyzn życia i sfer aktywności, w których będzie mogło odnosić sukcesy, a takimi często staje się świat wirtualny.

Wszystkie z przyczyn (przedstawione w schemacie 1) opierają się o brak skuteczności środowisk wychowawczych (zwłaszcza rodziny) w zaspokajaniu potrzeb 
dzieci i młodzieży, które w takiej sytuacji wybierają inne środowiska i grupy, będące w stanie odpowiedzieć na te sfrustrowane potrzeby.

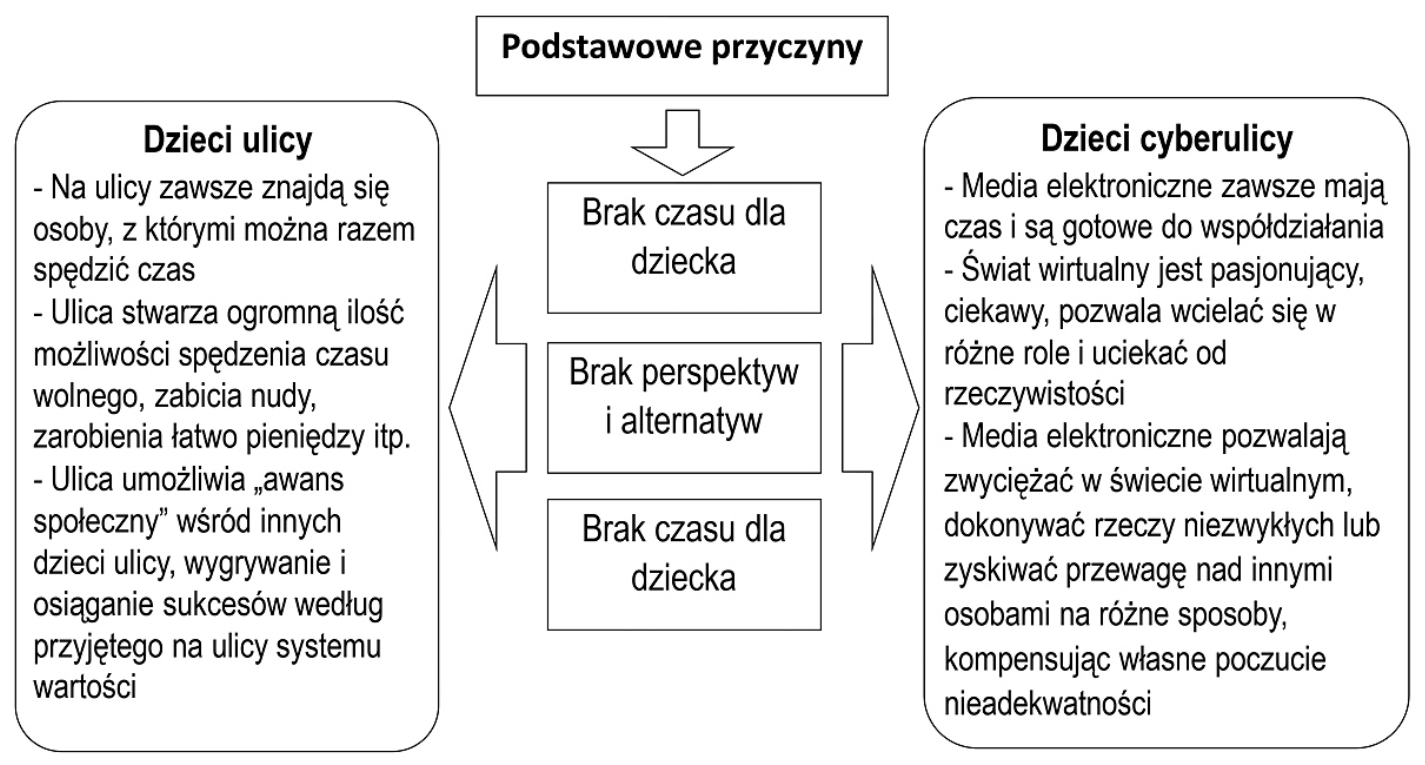

Schemat 1. Wspólne uwarunkowania zjawiska dzieci ulicy i dzieci cyberulicy

Źródło: opracowanie własne.

\section{Cyberulica jako przestrzeń życia oraz aktywności dzieci i młodzieży}

Cyberulicy nie należy traktować na równi z całą wirtualną przestrzenią i siecią internetową. Ulica wirtualna, podobnie jak realna, rządzi się swoimi prawami. Zbiera dzieci, które są pozbawione troski i uwagi ze strony swoich opiekunów, doświadczają chłodu emocjonalnego, porażek życiowych i nie mają innych perspektyw na zagospodarowanie swojego czasu. Jedną z najbardziej istotnych jej cech jest fakt braku rzeczywistej kontroli nad tym, co dziecko lub nastolatek robi, poruszając się po sieci. Wchodząc na cyber-ulicę, świat domowy zostawia za sobą, a zaczyna poruszać się po przestrzeni wirtualnej, niejednokrotnie z zawrotną prędkością, wykonując kilka czynności naraz.

Formy aktywności dzieci na ulicy wirtualnej są bardzo zbliżone do tych na prawdziwej ulicy, podobnie jak zagrożenia, na które są narażone. Można je pogrupować w cztery podstawowe obszary: zdobywanie pieniędzy, rozrywka, akty agresji oraz uzależnienia, co zostało przedstawione w tabeli 1. 
Tabela 1. Wspólne formy aktywności oraz zagrożenia na ulicy i cyberulicy

\begin{tabular}{|c|c|c|}
\hline & Dzieci ulicy & Dzieci cyberulicy \\
\hline 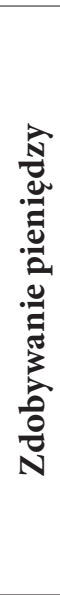 & $\begin{array}{l}\text { Podstawową formą zdoby- } \\
\text { wania pieniędzy na ulicy } \\
\text { jest żebractwo, ale również } \\
\text { drobne kradzieże, rozboje, } \\
\text { handel towarem (w tym } \\
\text { najczęściej narkotykami) } \\
\text { oraz prostytucja (np. ga- } \\
\text { lerianki) (Barczykowska, } \\
\text { Muskała 20o8) }\end{array}$ & $\begin{array}{l}\text { Przestrzenią zdobywania pieniędzy jest świat wirtualny, } \\
\text { dokonuje się to przeważnie w następujących formach: } \\
\text { - hackerstwo - przestępstwa dokonywane w sieci polegające } \\
\text { m.in. na kradzieży haseł, wyłudzaniu informacji, kradzieży } \\
\text { danych); } \\
\text { - handel obiektami rzeczywistymi i wirtualnymi, np. avata- } \\
\text { rami, kontami do gier itp.); } \\
\text { - kręcenie i publikowanie filmików, testów (blogi, kanały na } \\
\text { YouTube); } \\
\text { - seksting (wysyłanie za pomocą komputera lub telefonu tre- } \\
\text { ści i zdjęć o tematyce seksualnej, w tym wypadku za pienią- } \\
\text { dze lub za doładowania telefonu (Andrzejewska, Bednarek } \\
\text { 2o14) i publikowanie nagrań erotycznych (np. na Redtube). }\end{array}$ \\
\hline & $\begin{array}{l}\text { Podążanie za sensacją, } \\
\text { włóczenie się po ulicy, } \\
\text { po sklepach, okolicznych } \\
\text { parkach, organizowanie } \\
\text { sobie gier, zabaw, wyzwań, } \\
\text { wyśmiewanie i zaczepianie } \\
\text { innych, stosowanie różno- } \\
\text { rodnych używek itp. }\end{array}$ & $\begin{array}{l}\text { Surfowanie po internecie (oglądanie różnych stron, filmi- } \\
\text { ków, zdjęć, czytanie lub pisanie blogów), granie w różno- } \\
\text { rodne gry komputerowe i sieciowe, często niedostosowane } \\
\text { do wieku, pełne przemocy, okrucieństwa, negatywnych wzo- } \\
\text { rów zachowań (por. Andrzejewska) oraz udzielanie się na } \\
\text { forach tematycznych, oglądanie filmów i słuchanie muzyki, } \\
\text { pisanie na portalach społecznościowych. }\end{array}$ \\
\hline 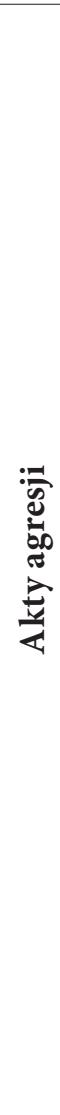 & $\begin{array}{l}\text { Bójki, kradzieże, bulling } \\
\text { wobec młodszych, słab- } \\
\text { szych, nielubianych osób, } \\
\text { wymuszenia, ośmieszanie } \\
\text { i poniżanie, przemoc } \\
\text { fizyczna }\end{array}$ & $\begin{array}{l}\text { Różnorodne formy przemocy i agresji elektronicznej, reali- } \\
\text { zowanej przez użycie nowych mediów - telefonów komórko- } \\
\text { wych i internetu: } \\
\text { - flaming - agresywne rozmowy na czatach, forach } \\
\text { internetowych; } \\
\text { - prześladowanie - regularne przesyłanie wiadomości } \\
\text { medialnych o charakterze agresywnym lub ośmieszającym } \\
\text { ofiary; } \\
\text { - kradzież tożsamości - podszywanie się pod ofiarę i wy- } \\
\text { konywanie w jej imieniu działań, które jej w konsekwencji } \\
\text { zaszkodzą; } \\
\text { - upublicznianie tajemnic - udostępnianie np. zdjęć, roz- } \\
\text { mów innym, np. w celu szantażu; } \\
\text { - śledzenie - nękanie i inwigilacja za pomocą mediów; } \\
\text { - happy slapping - prowokowanie lub atakowanie innej } \\
\text { osoby i dokumentowanie tego za pomocą nagrania lub zdjęć } \\
\text { (często udostępnianie potem w sieci); } \\
\text { - poniżenie - upublicznianie za pomocą mediów poniżają- } \\
\text { cych, nieprawdziwych materiałów dotyczących innych; } \\
\text { - agresja techniczna - atak skierowany przeciw np. oprogra- } \\
\text { mowaniu komputerowemu, stronie internetowej (Pyżalski } \\
\text { 2o12); } \\
\text { - hateing - obrażanie, wyzywanie, posługiwanie się języ- } \\
\text { kiem nienawiści w stosunku do jednostek lub całych grup } \\
\text { społecznych. } \\
\text { Wszystkie te formy noszą znamiona przemocy psychicznej } \\
\text { i mogą być tragiczne w skutkach }{ }^{A} \text {. }\end{array}$ \\
\hline
\end{tabular}




\begin{tabular}{|c|c|c|}
\hline & Dzieci ulicy & Dzieci cyberulicy \\
\hline & $\begin{array}{l}\text { Głównie od substancji psy- } \\
\text { choaktywnych (nikotyna, } \\
\text { alkohol, narkotyki), ale też } \\
\text { od dopalaczy, sterydów, } \\
\text { seksu itp. }\end{array}$ & $\begin{array}{l}\text { Uzależnienie od internetu, portali społecznościowych, gier } \\
\text { komputerowych i sieciowych (Adrzejewska 2014) oraz uza- } \\
\text { leżnienie od pornografii (cyberseksu), które jest masowym } \\
\text { zjawiskiem również wśród dzieci' } \\
\text { Nowym zagrożeniem są, jeszcze niezbadane w swoich } \\
\text { skutkach, e-narkotyki, czyli specjalnie przygotowane mate- } \\
\text { riały dźwiękowe, uruchomiane w odpowiednim programie } \\
\text { komputerowym, I-Doserze, w taki sposób, aby bazując na } \\
\text { różnych częstotliwościach dźwiękowych, stymulowały obie } \\
\text { półkule mózgowe, wywołując zamierzone rezultaty: od } \\
\text { różnych emocji, przez halucynacje aż do ekstazy (Tuszyńska- } \\
\text {-Bogucka, Kwiatkowski 2015). }\end{array}$ \\
\hline
\end{tabular}

Źródło: opracowanie własne.

A Konsekwencją agresji elektronicznej może być również przemoc w świecie realnym. Często zjawiska te przenikają się tak ściśle, że trudno stwierdzić, które z nich było pierwsze (Pyżalski 2011). Ofiary ceberprzemocy doświadczają szeregu trudnych emocji, a gdy stan ten jest przewlekły, w skrajnych przypadkach mogą dokonać zamachów na własne życie (Goetz 2018).

в Temat ten został omówiony m.in. na dwóch Międzynarodowych Konferencjach organizowanych przez Stowarzyszenie Twoja Sprawa: Konferencja „Społeczne i rozwojowe konsekwencje pornografii” odbyła się 22 czerwca 2015 roku w Sejmie RP, wystąpienia dostępne są na stronie stowarzyszenia: https://www.twojasprawa.org.pl/konferencja-spoleczne-i-rozwojowe-konsekwencje-pornografii; konferencja „Masowa konsumpcja pornografii przez dzieci jako istotny problem społeczny" odbyła się 21 listopada 2018 roku pod oficjalnym patronatem Instytutu Wymiaru Sprawiedliwości i Rzecznika Praw Dziecka. https://www.twojasprawa.org. $\mathrm{pl} /$ konferencja-masowa-konsumpcja-pornografii-przez-dzieci-jako-istotny-problem-spoleczny.

Poza opisanymi w tych obszarach zagrożeniami dla młodego człowieka na cybernetycznej ulicy można wymieniać też inne: zagrożenia dla rozwoju moralnego i przyswajalność społecznie nieakceptowanych norm i wartości (w internecie jest więcej negatywnych wzorów zachowań niż gdziekolwiek indziej oraz cechuje je trwałość w czasie, jedno bowiem nagranie lub gra mogą być wykorzystane niezliczoną liczbę razy), zagrożenia dla rozwoju tożsamości (poprzez tworzenie niezliczonych tożsamości w sieci i w grach komputerowych; trudno jest rozwijać własną tożsamość), dostęp do zagrażających treści i informacji, dotyczących m.in. środków uzależniających, treści satanistycznych czy szerzących różne formy przestępczości, zarówno w formie wirtualnej, jak i realnej. Świat cyberulicy, podobnie jak ulic miejskich, staje się w ten sposób swoistą niekontrolowaną szkołą demoralizacji i zachowań ryzykownych. 


\section{Formy pomocy i profilaktyki}

Zjawisko dzieci ulicy ze względu na swoje wieloletnie istnienie zostało już dość dobrze zbadane. Na całym świecie podejmuje się działania (o zróżnicowanym stopniu skuteczności), aby przeciwdziałać przyczynom tego fenomenu, jak również niwelować jego skutki. Działania takie prowadzone są m.in. przez UNICEF, międzynarodowe organizacje pozarząadowe (np. Czerwony Krzyż), misje organizowane przez różne zgromadzenia zakonne. Bogatego przeglądu organizacji, w ramach których streetworkerzy pracują z dziećmi ulicy, dokonała B. Adamczyk (2016).

W Polsce pomoc tym dzieciom należy do zadań polityki społecznej i jest realizowana przez samorządy (Pospiszyl 2014), które często współpracują z organizacjami pozarządowymi finansującymi ich działania. W ramach takiej współpracy prowadzone są m.in. środowiskowe ogniska wychowawcze i zatrudniani są pedagodzy podwórkowi oraz streetworkerzy. Organizowane są również profilaktyczne programy rządowe, szkolenia i kursy dla pedagogów i streetworkerów, opracowywane są nowe strategie pracy, a na konferencjach (np. Międzynarodowe FORUM Przyjaciół Dzieci Ulicy, organizowane przez KKWR) i przez publikacje następuje wymiana doświadczeń i wyników aktualnych badań. W literaturze przedmiotu podkreślana jest często konieczność wejścia w środowisko życia dzieci ulicy, co jest niezbędne dla zainicjowania pomocy (Kurzeja 2008; Olszewska-Baka, Pytka 2000).

Analogiczne działania są w dużej mierze podejmowane wobec dzieci uwikłanych w świat wirtualny. Na uwagę zasługują takie organizacje, jak Naukowa i Akademicka Sieć Komputerowa (NASK, https://akademia.nask.pl/o-nas/projekty. html) i Fundacja Dajemy Dzieciom Siłę (https://fdds.pl), które podejmują wiele ważnych inicjatyw profilaktyczno-informacyjnych i pomocowych, np. organizują Dzień Bezpiecznego Internetu, szkolenia i warsztaty związane z tematyką cyberprzestrzeni, przeznaczone dla nauczycieli, pedagogów oraz rodziców, prowadzą kampanie społeczne (np. „Nie zagub dziecka w sieci”; „Nie hejtuję-reaguję”; „Internetowe okno na świat” - ochrona dzieci przed niebezpiecznymi treściami w internecie; „Myślę, więc nie ślę” - kampania poświęcona problemowi sekstingu), współtworzą stronę Sieciaki.pl, wydają materiały szkoleniowe i informacyjne, organizują międzynarodowe konferencje poświęcone bezpieczeństwu dzieci w sieci itp. Wyczerpującego przeglądu działań profilaktycznych w obszarze zagrożeń cyberprzestrzeni dla dzieci dokonała Aleksandra Kubala-Kulpińska (2018). Mimo że oferta szkoleniowo-profilaktyczna i informacyjna związana z omawianą problematyką jest dosyć obszerna, to jednak wymaga stałego poszerzania o nowe zagrożenia.

Niestety, prezentowane działania, choć są bardzo cenne i mogą być skuteczne w odniesieniu do zwykłych młodych użytkowników internetu i ich rodzin, to jednak w przypadku dzieci cyberulicy są wciąż niewystarczające. Należy wejść w środowisko, w którym te dzieci przebywają - w innym wypadku w dalszym ciągu pozostają one poza wpływem wszelkich kampanii poświęconych temu zjawisku. Dlatego niezbędne jest przygotowanie do takiej funkcji pedagogów i nauczycieli, 
którzy nawiązywaliby kontakt $\mathrm{z}$ dziećmi cyberulicy na portalach społecznościowych, forach, czatach, udzielali im wsparcia, a w razie potrzeby - interweniowali. Jest to zadanie niezwykle trudne, wymagające nie tylko odpowiedniego przygotowania networkerów, lecz również stworzenia artykułów prawnych regulujących ich pracę, zapewniających odpowiednie uprawnienia oraz współpracę z organami i służbami państwowymi (np. policją).

\section{Podsumowanie i wnioski}

Nie wszystkie dzieci sieci są dziećmi cyberulicy, tak jak nie wszystkie dzieci spędzające czas na podwórkach są dziećmi ulicy. Obecnie korzystanie z cyberprzestrzeni jest zjawiskiem całkowicie naturalnym, a wielokrotnie koniecznym, staliśmy się bowiem członkami społeczeństwa sieciowego. Należy jednak zwrócić szczególną uwagę na czynniki ryzyka, jakie niesie ze sobą korzystanie przez dzieci i młodzież $\mathrm{z}$ technologii informacyjnych i komunikacyjnych, zwłaszcza gdy odbywa się to poza kontrolą osób dorosłych.

Kampanie społeczne, kursy i szkolenia, poświęcane zagrożeniom medialnym, są w dzisiejszych czasach coraz częstsze, jednak nie wypełniają powstałej luki w działaniach wspierających rozwój dzieci i młodzieży, które już na wirtualnej ulicy żyją, zarabiają i spędzają swój wolny czas. Pedagogika, której zadaniem jest odpowiadanie na powstające $\mathrm{w}$ świecie zagrożenia wychowawcze, musi nie tylko nadążać za nowymi badaniami w rozwoju teorii i badań, lecz także proponować praktyczne rozwiązania problemów, co może wiązać się ze zrewolucjonizowaniem całego sposobu i metod kształcenia przyszłych pedagogów, tak aby byli oni nie tylko wyposażeni w wypracowane i sprawdzone sposoby działania, ale również posiadali umiejętności samodzielnej i krytycznej analizy nowopowstających zjawisk oraz potrafili adekwatnie do sytuacji projektować i realizować najbardziej optymalne działania.

Nie można też zapomnieć o likwidowaniu ogólnych przyczyn zjawiska poprzez szeroką pracę z rodziną, wzmacnianie relacji małżeńskich i więzi rodzinnych, budowanie rozsądnej polityki prorodzinnej państwa w taki sposób, aby to właśnie rodzina, a nie ulica była miejscem przebywania dzieci i młodzieży oraz ich rozwoju, miejscem zaspokajania ich potrzeb fizycznych i psychicznych.

\section{Bibliografia}

Adamczyk B. (2015). Dzieci ulicy w Polsce i na świecie. Definicja. Typologia. Etiologia. Kraków: Akademia Ignatianum, Wydawnictwo WAM.

Andrzejewska A. (2014). Dzieci i młodzież w sieci zagrożeń realnych $i$ wirtualnych. Warszawa: Difin. 
Andrzejewska A., Bednarek J. (2014). Seksting. W: Zagrożenia cyberprzestrzeni. Kompleksowy program dla pracowników służb społecznych. Lizut J. (red.). Warszawa: WSP im. J. Korczaka.

Babicki Z. (2017). Idea wychowania do pokoju w programach pomocowych dzieciom w Afryce. „Forum Pedagogiczne”, nr 1, s. 211-226.

Barczykowska A., Muksała M. (2008). Dzieci ulicy „w sercach miast”. „Czasopismo Techniczne. Architektura”, nr 2-A (105), s. 23-29.

Bardziejewska M. (2004). Okres dorastania - szanse rozwoju, „Remedium”, nr 11 (129), s. 4-5.

Brandes D., Specht W. (2000). Praca z dziećmi ulicy w European Network on Street Children Worldwide (ENSCW) i International Society for Mobil Youyth Work. W: Dzieci ulicy. Problemy, profilaktyka, resocjalizacja. Olszewska-Baka G. (red.). Białystok: eRBe.

Brzeziński M. (2013). Dzieci ulicy. Ujęcie pastoralno-teologiczne. W: Granice streetworkingu. Jęczeń J., Lelonek-Kuleta B. (red.). Sandomierz-Lublin-EichstättIngolstadt: POLIHYMNIA.

Drapała-Petryka I. (2014). Kultura szybkostrzelna/kultura „natłoku”- jałowym gruntem dla rozwoju człowieka. W: Współcześni ludzie wobec wyzwań i zagrożeń XXI wieku. Liberska H., Malina A., Suwalska-Barancewicz D. (red.). Warszawa: Difin.

Fidelus A. (2005a). Dzieci ulicy - podobieństwa i różnice w zależności od czynników środowiskowych. W: Uwarunkowania i wzory marginalizacji społecznej współczesnej młodzieży. Kubik W., Urban B. (red.). Kraków: Wydawnictwo WAM.

Fidelus A. (2005b). Zjawisko „dzieci ulicy” jako współczesny problem społeczny. „Studia nad Rodziną”, nr 2 (17), s. 125-135.

Goetz M. (2018). Internetowy hejt po obu stronach monitora: konsekwencje cyberprzemocy. „Świat Problemów”, nr 9, s. 13-16.

Kubala-Kulpińska A. (2017). Profilaktyka zagrożeń w cyberprzestrzeni wśród najmłodszych. „Życie Szkoły”, nr 2, s. 29-31.

Kołak W. (2002). Prawa dzieci ulicy w działalności KKWR. „Opieka, Wychowanie, Terapia", nr 1, s. 4-6.

Kołodziejczyk T. (200o). Program Street Children-Children of the Streets $w$ Polsce. W: Dzieci ulicy. Problemy, profilaktyka, resocjalizacja. Olszewska-Baka G. (red.). Białystok: eRBe.

Kostka M. (1998). „Młodzieży zagrożonej trzeba szukać...”. „Opieka, Wychowanie, Terapia" nr 2, s. 22-23.

Kozak S. (2011). Patologie komunikowania w Internecie. Zagrożenia i skutki dla dzieci i młodzieży. Warszawa: Difin.

Krzystanek K. (2004). Wpływ agresywnych gier komputerowych na poziom agresywności gracza. W: Agresja w szkole. Spojrzenie wieloaspektowe. Rejzner A. (red.). Warszawa: Wydawnictwo Wyższej Szkoły Pedagogicznej TWP.

Kubala-Kulpińska A. (2017). Profilaktyka zagrożeń w cyberprzestrzeni wśród najmłodszych. „Życie Szkoły”, nr 2, s. 29-31. 
Kurzeja A. (2008). Dzieci ulicy. Profilaktyka zagrożeń. Kraków: Oficyna Wydawnicza Impuls.

Lachowska B. (2010). Style rozwiązywania konfliktów $i$ ich efekty $w$ relacji między rodzicami a adolescentami - prezentacja narzędzi pomiaru. W: Sytuacje konfliktu $w$ środowisku rodzinnym, szkolnym i rówieśniczym. Jak sobie radzą z nimi dzieci i młodzież. Borecka-Biernat D. (red.). Warszawa: Difin.

Olszewska-Baka G., Pytka, L. (2000). „Dzieci ulicy” - metodologiczne aspekty profilaktyki interwencyjnej. W: Dzieci ulicy. Problemy, profilaktyka, resocjalizacja. Olszewska-Bak G. (red.). Białystok: eRBe.

Olszewska-Baka G., Pytka, L. (1999). Wychowanie i pomoc w środowisku otwartym. „Opieka, Wychowanie, Terapia”, nr 1, s. 27-32.

Pilch T. (200o). Dziecko ulicy - ewolucja pojęcia. „Opieka, Wychowanie, Terapia”, nr 1, s. 5-8.

Pilch T. (2010). Miliard dzieci bez szczęścia. „Chowanna”, nr 1, s. 41-48.

Pospiszyl I. (2014). Patologie społeczne. Warszawa: Wydawnictwo Naukowe PWN.

Pyżalski J. (2012). Agresja elektroniczna i cyberbullying jako nowe ryzykowne zachowania młodzieży. Warszawa: Impuls.

Ryś, M. (2011). Kształtowanie się poczucia własnej wartości i relacji z innymi w różnych systemach rodzinnych. „Kwartalnik Naukowy Fides et Ratio”, nr 2 (6), s. $64-83$.

Tempczyk-Nagórka, Ż. (2016). Zagrożenia dla rozwoju tożsamości i zdrowia psychicznego człowieka. W: Kałdon B. (red.). Wybrane obszary niebezpieczeństw XXI wieku w ujęciu interdyscyplinarnym. Warszawa: Wydawnictwo Naukowe UKSW.

Tuszyńska-Bogucka W., Kwiatkowski P. (2015) „Naćpani dźwiękiem”? E-narkotyki jako obszar badań przyszłości, „Horyzonty Psychologii”, nr 5, s. 29-43.

Żelazny R. (2014). Praktyczne aspekty pomiaru poziomu rozwoju społeczeństwa informacyjnego w wymiarze mezoekonomicznym. Dostępny na: http://www.pte. $\mathrm{pl} /$ kongres/referaty/?dir=Zelazny+Rafa\%C5\%82 (otwarty: 28.12.2019).

\title{
FROM STREET CHILDREN TO CYBER-STREET CHILDREN
}

\begin{abstract}
The phenomenon of street children is more and more recognized and analysed theoretically and empirically. It has many faces depending on socio-economic and cultural factors. Facing the rapid development of information society, it transforms in many aspects. As a result, a growing number of street children living in well-off families but who are emotionally neglected, spend a lot of time in cyberspace with no parental control. Therefore, these children may be called "cyber-street children". The aim of this article is to study connections between conditions, forms of activities taken by street children, danger and prevention.
\end{abstract}

Keywords: street children; cyber threats; streetworking; network therapy; dysfunctions of family. 